\title{
Monoclonal Antibody Against the Turn of the 42-Residue Amyloid $\beta$-Protein at Positions 22 and 23
}

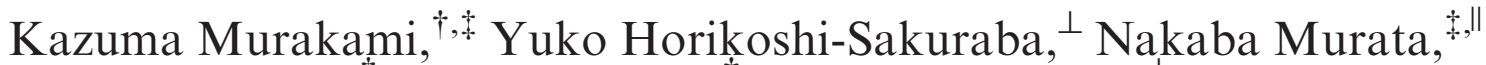 \\ Yoshihiro Noda, ${ }^{\dagger}$ Yuichi Masuda, ${ }^{\dagger}$ Noriaki Kinoshita,${ }^{\perp}$ Hiroyuki Hatsuta,, \\ Shigeo Murayama, ${ }^{\S}$ Takuji Shirasawa, ${ }^{\#}$ Takahiko Shimizu, ${ }^{*}$, and Kazuhiro Irie, ${ }^{*}$ \\ ${ }^{\dagger}$ Division of Food Science and Biotechnology, Graduate School of Agriculture, Kyoto University, Kyoto 606-8502, Japan, ${ }^{*}$ Molecular \\ Gerontology and ${ }^{\S}$ Department of Neuropathology, Tokyo Metropolitan Institute of Gerontology, Itabashi-ku, Tokyo 173-0015, \\ Japan, ${ }^{\perp}$ Immuno-Biological Laboratories Co, Ltd., Gunma 370-0831, Japan, "Applied Biological Chemistry, United Graduate School of \\ Agricultural Science, Tokyo University of Agriculture and Technology, Fuchu-shi, Tokyo 183-8509, Japan, and ${ }^{\#}$ Department of Aging \\ Control Medicine, Juntendo University Graduate School of Medicine, Bunkyo-ku, Tokyo 113-0033, Japan
}

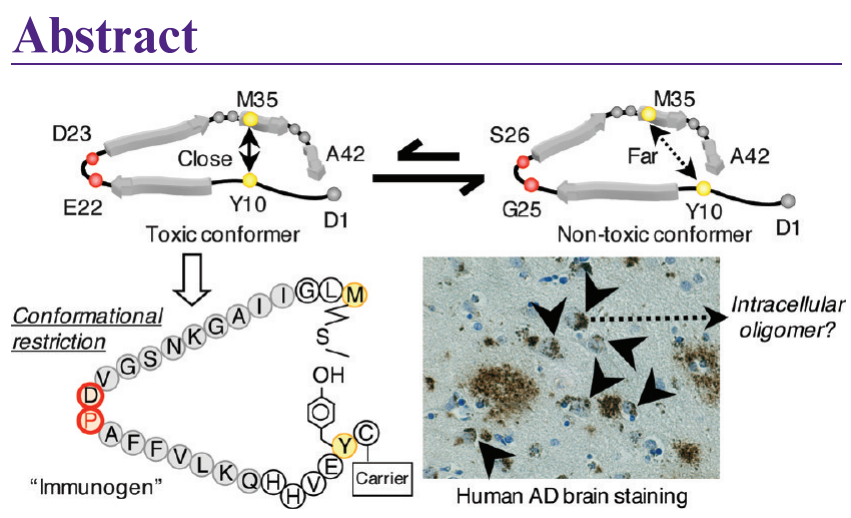

Aggregation of the 42-mer amyloid $\beta$-protein $(\mathrm{A} \beta 42)$ plays a critical role in the pathogenesis of Alzheimer's disease (AD). We have proposed a toxic conformer with a turn at positions 22 and 23 , as well as a nontoxic conformer with a turn at positions 25 and 26, in A $\beta 42$ aggregates from systematic proline scanning and solidstate NMR studies. Although recent clinical trials of immunization targeting $\mathrm{A} \beta 42$ aggregates have proved useful, some adverse effects were reported. One of the reasons was hypothesized to be excessive immunoreactions derived from the unintended removal of nontoxic $\mathrm{A} \beta 42$, which plays an important role in the physiological function. To develop a monoclonal antibody for toxic $\mathrm{A} \beta 42$, $\mathrm{E} 22 \mathrm{P}-\mathrm{A} \beta 10-35$, a minimum moiety for neurotoxicity containing the turn at positions 22 and 23 , was used for the generation of antibodies, following the selection of clones using $\mathrm{A} \beta 42$ mutants of E22P (turn-inducing) and E22V (turn-preventing). The obtained clone (11A1) showed a high binding affinity $\left(K_{\mathrm{D}}=10.3 \mathrm{nM}\right)$ for $\mathrm{A} \beta 42$ using surface plasmon resonance. 11A1 also inhibited the neurotoxicity of $\mathrm{A} \beta 42$ in PC12 cells. Immunohistochemical studies showed that not only extracellular but intracellular amyloid was stained in human AD brains. In Western blotting analyses using human brains, low-molecular weightoligomers rather than the monomer of $\mathrm{A} \beta$ were readily recognized by $11 \mathrm{~A} 1$. These results imply that $11 \mathrm{~A} 1$ could detect toxic $\mathrm{A} \beta 42$ oligomers with the turn at positions
22 and 23 and that 11A1 could be applicable for the therapeutic targeting of toxic $\mathrm{A} \beta 42$ in $\mathrm{AD}$.

Keywords: amyloid, Alzheimer's disease, neurotoxicity, turn, human brain, transgenic mice

1 lzheimer's disease (AD) is generally characterized by amyloid deposition in senile plaques that are mainly composed of 40- and 42-mer amyloid $\beta$-proteins $(\mathrm{A} \beta 40$ and $\mathrm{A} \beta 42)(1,2)$. These proteins are produced from amyloid precursor protein (APP) by two proteases, $\beta$ - and $\gamma$-secretases. A $\beta 42$ plays a more important role in the pathogenesis of AD than A $\beta 40$ because of its stronger aggregative ability and neurotoxicity (3). Oxidative stress is suggested to contribute to neurodegeneration associated with $\mathrm{AD}(4-6)$. One of the proposed mechanisms of the neurotoxicity of $\mathrm{A} \beta 42$ is related to radicalization at both Tyr 10 and Met35 accompanied by the generation of hydrogen peroxide (7). On the other hand, there is substantial evidence that the oligomeric assembly of $\mathrm{A} \beta 42$ could induce AD via synaptotoxicity $(8,9)$.

Immunization against $A \beta$ is considered to be a promising approach for AD therapy because vaccination of transgenic mouse models of $\mathrm{AD}$ with $\mathrm{A} \beta 42$ aggregates resulted in a reduction of $\mathrm{A} \beta$ deposition and the prevention of cognitive impairment $(10,11)$. However, clinical trials (AN1792) of immunization of AD patients against $\mathrm{A} \beta 42$ were interrupted because of severe adverse effects of excessive immune activation (12). Recently, a follow-up study has shown that immunization against $\mathrm{A} \beta 42$ suppressed $\mathrm{A} \beta$ depositions in $\mathrm{AD}$ patients but not the progressive cognitive impairment (13). One of the reasons for these problems might be the unintended elimination of both toxic and nontoxic forms of $\mathrm{A} \beta 42$,

Received Date: August 4, 2010

Revised Manuscript Received: September 18, 2010

Published on Web Date: September 28, 2010 


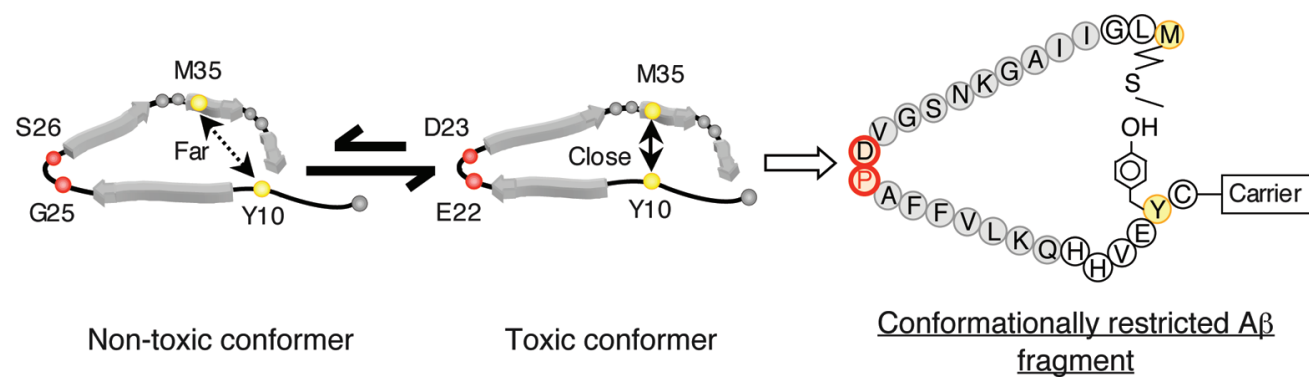

Figure 1. Nontoxic and toxic conformations of $\mathrm{A} \beta 42$ identified by our previous studies using solid-state NMR (15). The turn positions are different from each other. On the basis of the toxic conformation with a turn at positions 22 and 23 , a conformationally restricted A $\beta$ fragment was optimized as an immunogen to develop antibodies targeting toxic $\mathrm{A} \beta 42$.

whose role in physiological function is controversial at present. Quite recently, Tanzi and colleagues proposed the relevance of $\mathrm{A} \beta 42$ to the innate immune system as an antimicrobial protein (14). A $\beta 42$ may have one conformer with the normal function required for brain regulation. Therefore, the discrimination of nontoxic from toxic $\mathrm{A} \beta 42$ is indispensable to block the progression of $\mathrm{AD}$ pathology and cognitive dysfunction effectively.

A recent investigation using solid-state NMR together with systematic proline replacement differentiated the toxic conformer with a turn at positions 22 and 23 in A $\beta 42$ aggregates from the nontoxic one with a turn at positions 25 and 26; the former showed potent aggregative ability and neurotoxicity (15) (Figure 1). At least two conformers can exist in an equilibration of $\mathrm{A} \beta 42$. To generate a monoclonal antibody for toxic $\mathrm{A} \beta 42$, E22P-A $\beta 10-35$, which contains both Tyr 10 and Met35 required for neurotoxicity (7) and the turn at positions 22 and 23 as a Pro- $\mathrm{X}$ corner $(\mathrm{X}=$ variable amino acid residue) (16), was used as the immunogen (Figure 1). This paper describes the development and characterization of the $11 \mathrm{~A} 1$ monoclonal antibody that was designed to target the toxic conformer of $\mathrm{A} \beta 42$. The $11 \mathrm{~A} 1$ antibody demonstrated a high binding affinity for $\mathrm{A} \beta 42$ in surface plasmon resonance (SPR) analyses, inhibited A $\beta 42$-induced neurotoxicity in PC12 cells, detected intracellular as well as extracellular $\mathrm{A} \beta$ in $\mathrm{AD}$ brain sections, and recognized low-molecular weight-oligomers rather than monomers of $\mathrm{A} \beta$ in $\mathrm{AD}$ brain extracts.

\section{Results and Discussion}

\section{Development and Characterization of Monoclonal Antibody 11A1 against the Toxic Conformer of $\mathrm{A} \boldsymbol{\beta} 42$}

Clones were selected based on the ability to react with $\mathrm{A} \beta 42$ mutants that have a propensity to form a $\beta$-turn at positions 22 and 23 (17) (e.g., E22Q-A $\beta 42$, E22G-A $\beta 42$, E22K-A $\beta 42$, E22P-A $\beta 42$, and D $23 \mathrm{~N}-\mathrm{A} \beta 42)$, to obtain a unique clone named 11A1. As shown in Figure 2A (left), $11 \mathrm{~A} 1$ showed stronger immunoreactivity with E22P$\mathrm{A} \beta 42$ than $\mathrm{A} \beta 42$ and $\mathrm{A} \beta 40$, but weak affinity to $\mathrm{E} 22$
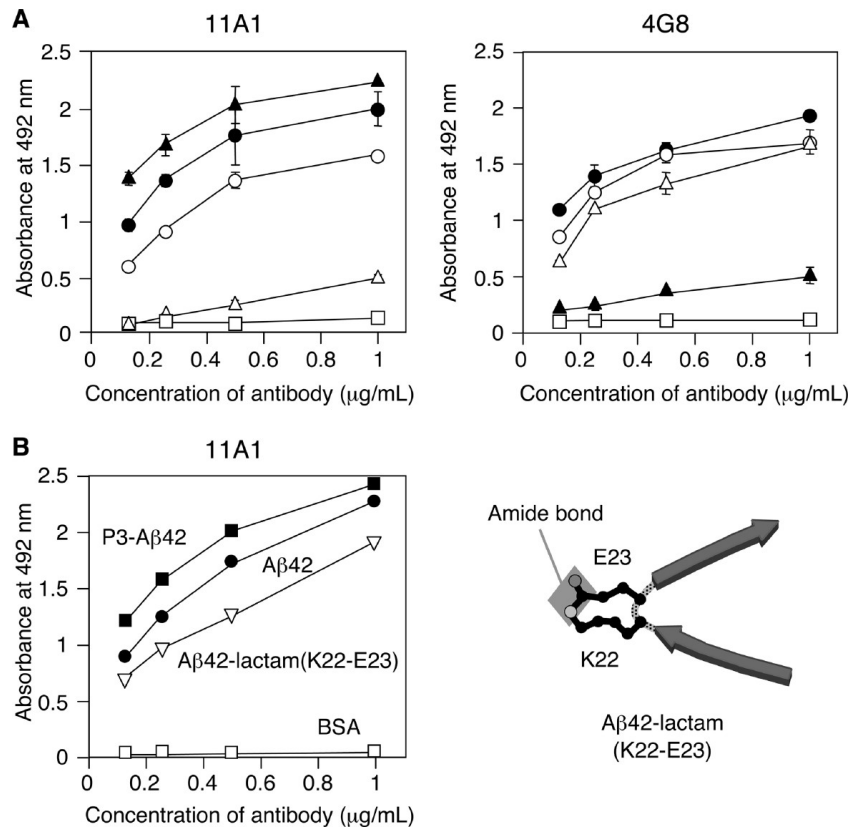

Figure 2. (A) Enzyme immunoassay of $11 \mathrm{~A} 1$ (left) and 4G8 (right) monoclonal antibodies at concentrations of $0.125,0.25,0.5$, and $1.0 \mu \mathrm{g} / \mathrm{mL}$ on $\mathrm{A} \beta 42$ mutants coated on to 96 -well plates:, $\mathrm{A} \beta 42$; $\mathrm{O}, \mathrm{A} \beta 40 ; \mathbf{\Delta}, \mathrm{E} 22 \mathrm{P}-\mathrm{A} \beta 42 ; \Delta, \mathrm{E} 22 \mathrm{~V}-\mathrm{A} \beta 42 ; \square, 0.1 \%$ (w/v) BSA. (B) Enzyme immunoassay of $11 \mathrm{~A} 1$ antibody at concentrations of $0.125,0.25,0.5$, and $1.0 \mu \mathrm{g} / \mathrm{mL}$ with $\mathrm{A} \beta 42$ mutants: $\bullet, \mathrm{A} \beta 42$; 口, P3-A $\beta 42 ; \nabla, \mathrm{A} \beta 42-\operatorname{lactam}(22 \mathrm{~K}-23 \mathrm{E}) ; \square, 0.1 \%(\mathrm{w} / \mathrm{v}) \mathrm{BSA}$ and the structure of $\mathrm{A} \beta 42-\operatorname{lactam}(\mathrm{K} 22-\mathrm{E} 23)$.

$\mathrm{V}-\mathrm{A} \beta 42$, in which valine was used as a turn breaker (16). 11A1 appeared not be proline residue specific since $11 \mathrm{~A} 1$ bound to E22P-A $\beta 42$, as well as $\mathrm{A} \beta 42$ to a similar extent. Our recent reports have examined conformationally restricted analogues of $\mathrm{A} \beta 42$ with a turn at positions 22 and 23: A $\beta 42$-lactam (K22-E23, Figure 2B, right), in which the side chains at positions 22 and 23 were linked covalently (15), and the triple $\mathrm{A} \beta 42$ mutant $(\mathrm{P} 3-\mathrm{A} \beta 42)$ with proline residues substituted at the three possible turn positions $(22,34$, and 38$)(18)$. 11A1 also bound efficiently to these mutants in a dose-dependent manner (Figure 2B, left). Therefore, 11A1 was thought to be sensitive to a turn at positions 22 and 23 of $\mathrm{A} \beta$. The highly similar immunoreactivity of $11 \mathrm{~A} 1$ for $\mathrm{A} \beta 40$ and 


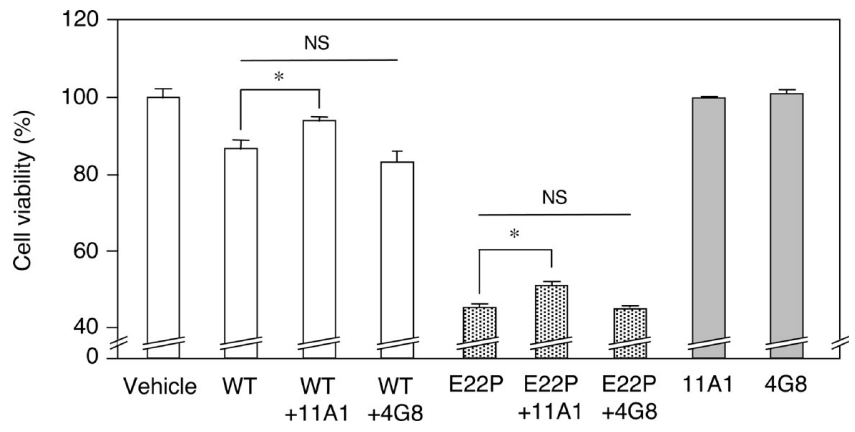

Figure 3. Neurotoxicity of $\mathrm{A} \beta 42(\mathrm{WT})$ and E22P-A $\beta 42(0.1 \mu \mathrm{M})$ in $\mathrm{PC} 12$ cells, and their inhibition by $11 \mathrm{~A} 1$ or $4 \mathrm{G} 8$ antibodies $(0.36 \mu \mathrm{M}, 0.054 \mathrm{mg} / \mathrm{mL})$ estimated by MTT assay. Antibodies alone were used as the controls. ${ }^{*} p<0.05$. Data are expressed as mean \pm sem. NS: not significant.

A $\beta 42$ (Figure 2A, left) might indicate the common presence of the turn at positions 22 and 23 of both $A \beta 42$ and $\mathrm{A} \beta 40$. The existence of a turn at positions 22 and 23 in $\mathrm{A} \beta 42$ and $\mathrm{A} \beta 40$ was deduced from systematic proline replacement by us (18) and Wetzel's group (19), respectively.

On the other hand, a conventional anti-A $\beta 17-24$ antibody, 4G8 (20), showed weak reactivity with E22P$\mathrm{A} \beta 42$, while it bound effectively to $\mathrm{E} 22 \mathrm{~V}-\mathrm{A} \beta 42$, as well as $\mathrm{A} \beta 42$ and $\mathrm{A} \beta 40$ (Figure $2 \mathrm{~A}$, right). These results suggested that $4 \mathrm{G} 8$ could not recognize the turn structure at positions 22 and 23 because E22V-A $\beta 42$ could not readily form a turn structure at this position (17). The opposite reactivity of $4 \mathrm{G} 8$ from $11 \mathrm{~A} 1$ for the $\mathrm{A} \beta 42$ mutants (Figure $2 \mathrm{~A}$ ) was reasonable because $4 \mathrm{G} 8$ could be residue specific; its epitope lies within the amino acids at positions $17-24(20)$.

The dissociation constant $\left(K_{\mathrm{D}}=k_{\mathrm{d}} / k_{\mathrm{a}}\right)$ of $11 \mathrm{~A} 1$ for $\mathrm{A} \beta 42$ calculated from the association $\left(k_{\mathrm{a}}\right)$ and dissociation $\left(k_{\mathrm{d}}\right)$ rate constants was determined from experiments using SPR. 11A1 showed a high binding affinity for $\mathrm{A} \beta 42\left(K_{\mathrm{D}}=10.3 \mathrm{nM}, k_{\mathrm{a}}=50.5 \times 10^{3} \mathrm{M}^{-1} \mathrm{~s}^{-1}\right.$, $\left.k_{\mathrm{d}}=0.522 \times 10^{-3} \mathrm{~s}^{-1}\right)$.

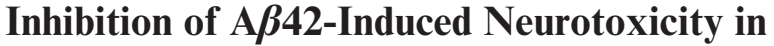 PC12 Cells by 11A1}

$\mathrm{A} \beta 42$-induced neurotoxicity in $\mathrm{PC} 12$ cells in the presence or absence of 11A1 was determined using the MTT method (Figure 3). PC12 cells treated with $\mathrm{A} \beta 42$ at $0.1 \mu \mathrm{M}$ showed lower viability than the control cells, and this toxicity was blocked by $11 \mathrm{~A} 1$ at $0.36 \mu \mathrm{M}(0.054 \mathrm{mg} / \mathrm{mL})$ in a statistically significant manner. On the other hand, $4 \mathrm{G} 8$ antibody failed to inhibit $\mathrm{A} \beta 42$-induced cytotoxicity. Moreover, the neurotoxicity by E22P-A $\beta 42(0.1 \mu \mathrm{M})$, which can more readily form the toxic conformer of $\mathrm{A} \beta 42$ than wild-type $\mathrm{A} \beta 42$ (15), was also inhibited by $11 \mathrm{~A} 1$, but not by $4 \mathrm{G} 8$. These antibodies at $0.36 \mu \mathrm{M}$ did not affect cell viability (Figure 3 ).

Although the inhibition of $\mathrm{A} \beta 42$ or E22P-A $\beta 42-$ induced toxicity by $11 \mathrm{~A} 1$ is significant, the effect is not large, in contrast to the results in Figure 2. One of the reasons is presumably due to the difference of the ratio for $\mathrm{A} \beta$ doses to those of antibodies in the two independent experiments (Figures 2 and 3). Alternatively, the difference of experimental conditions will be assumed; the $\mathrm{A} \beta$-immobilized plate in the enzyme immuno assay was used (Figure 2), while the culture in the cell test was utilized (Figure 3). Another possibility might be the lower effective concentration of 11A1 induced from the limitation of $11 \mathrm{~A} 1$ solubility than $4 \mathrm{G} 8$; the concentrations of $11 \mathrm{~A} 1$ and $4 \mathrm{G} 8$ after incubation for $48 \mathrm{~h}$ at $37^{\circ} \mathrm{C}$ were 0.38 and $0.93 \mathrm{mg} / \mathrm{mL}$ (before incubation; 0.54 and $1.0 \mathrm{mg} / \mathrm{mL}$ ), respectively. These results imply that $11 \mathrm{~A} 1$ might be less stable, resulting in lower inhibition of A $\beta 42$-induced cytotoxicity by $11 \mathrm{~A} 1$ than expected. This problem of its solubility and stability should be solved before its application for therapy by improving the purification method (column, cell culture condition, and so on).

\section{Detection of Intracellular as well as Extracellular $\mathrm{A} \beta$ in Human AD Brains by 11A1}

Immunohistochemical studies of $11 \mathrm{~A} 1$ and $4 \mathrm{G} 8$ antibodies were carried out using the frontal lobe and hippocampus regions of autopsied brains from $17 \mathrm{AD}$ and 18 non-AD individuals (Table 1). As shown in Figure 4A (left), both antibodies reacted with typical amyloid plaques in the frontal lobe of $\mathrm{AD}$ patients, whereas interestingly some intracellular staining was detected only by treatment with 11A1 (Figure 4A, arrowheads). $11 \mathrm{~A} 1$ showed mild intracellular staining even in nonAD individuals (Figure 4A, right). A similar pattern of intracellular as well as extracellular staining was observed in 11A1-treated hippocampus section of the same brains (Figure 4B). The evaluation of staining for senile plaques and intracellular amyloid in all 35 subjects is summarized in Table 1. To eliminate the possibility that this intracellular staining was nonspecific for amyloid, inhibition of the staining by the immunogen of $11 \mathrm{~A} 1$ was investigated (Figure 5). Preincubation of $11 \mathrm{~A} 1$ with its immunogen (200-fold molar excess) resulted in no staining in $\mathrm{AD}$ brain sections, indicating that $11 \mathrm{~A} 1$ could detect $\mathrm{A} \beta$ within the cells as well as senile plaques (Figure 5, upper). In a control experiment, $4 \mathrm{G} 8$ did not react at all with the immunogen of $11 \mathrm{~A} 1$ (Figure 5, lower).

Moreover, immunohistochemical studies of 11A1 were performed using two representative APP transgenic mice, Tg2576 (28 months old) and J20 (12 months old). However, the intracellular staining of amyloid in humans was weakly observed in mice, although senile plaques were detected significantly (Figure 6). It is notable that the intracellular amyloid detected by $11 \mathrm{~A} 1$ was stained only in human brain sections but weakly in those of APP transgenic mice ( $\mathrm{Tg} 2576$ and $\mathbf{J} 20$ ). This was similar to 
Table 1. Summary of Neuropathological Diagnosis and Immunohistochemical Data ${ }^{a}$

\begin{tabular}{|c|c|c|c|c|c|c|c|}
\hline \multirow[b]{2}{*}{ case } & \multirow[b]{2}{*}{ age } & \multirow[b]{2}{*}{ sex } & \multirow[b]{2}{*}{ CDR } & \multirow[b]{2}{*}{ Braak } & \multicolumn{2}{|c|}{$11 \mathrm{~A} 1$} & \multirow[b]{2}{*}{ NP diagnosis } \\
\hline & & & & & SP & IA & \\
\hline 1 & 96 & $\mathrm{M}$ & 3 & 6 & +++ & ++ & $\mathrm{AD}$ \\
\hline 2 & 83 & $\mathrm{~F}$ & 3 & 5 & +++ & +++ & $\mathrm{AD}$ \\
\hline 3 & 84 & M & 3 & 5 & ++ & ++ & $\mathrm{AD}$ \\
\hline 4 & 86 & $\mathrm{~F}$ & 1 & 5 & +++ & ++ & $\mathrm{AD}$ \\
\hline 5 & 91 & $\mathrm{~F}$ & 1 & 5 & ++ & +++ & $\mathrm{AD}$ \\
\hline 6 & 82 & $\mathrm{~F}$ & 3 & 5 & +++ & +++ & $\mathrm{AD}$ \\
\hline 7 & 86 & $\mathrm{~F}$ & 3 & 6 & ++ & ++ & $\mathrm{AD}$ \\
\hline 8 & 84 & M & 2 & 6 & +++ & ++ & $\mathrm{AD}$ \\
\hline 9 & 76 & M & 3 & 6 & ++ & ++ & $\mathrm{AD}$ \\
\hline 10 & 84 & $\mathrm{~F}$ & 3 & 5 & ++ & + & $\mathrm{AD}$ \\
\hline 11 & 84 & $\mathrm{~F}$ & 2 & 4.5 & ++ & ++ & $\mathrm{AD}$ \\
\hline 12 & 86 & $\mathrm{~F}$ & 3 & 5 & ++ & ++ & $\mathrm{AD}$ \\
\hline 13 & 87 & $\mathrm{~F}$ & 3 & 5 & ++ & +++ & $\mathrm{AD}$ \\
\hline 14 & 74 & M & 0 & 5 & +++ & ++ & $\mathrm{AD}$ \\
\hline 15 & 82 & $\mathrm{~F}$ & 1 & 5 & ++ & + & $\mathrm{AD}$ \\
\hline 16 & 81 & M & 2 & 6 & ++ & + & $\mathrm{AD}$ \\
\hline 17 & 87 & M & 3 & 6 & +++ & ++ & $\mathrm{AD}$ \\
\hline 18 & 79 & M & 0.5 & 2 & - & + & non-AD \\
\hline 19 & 80 & $\mathrm{~F}$ & 0 & 2 & - & ++ & non-AD \\
\hline 20 & 82 & $\mathrm{~F}$ & $\mathrm{~N} / \mathrm{A}$ & 2 & - & + & non-AD \\
\hline 21 & 80 & M & 0 & 2 & + & + & non-AD \\
\hline 22 & 75 & M & 0 & 1 & - & + & non-AD \\
\hline 23 & 69 & M & $\mathrm{N} / \mathrm{A}$ & 1 & - & - & non-AD \\
\hline 24 & 70 & M & 0 & 1 & - & + & non-AD \\
\hline 25 & 68 & M & 0 & 1 & - & + & non-AD \\
\hline 26 & 67 & M & $\mathrm{N} / \mathrm{A}$ & 1 & + & + & non-AD \\
\hline 27 & 67 & M & 0 & 2 & + & - & non-AD \\
\hline 28 & 80 & M & 0.5 & 2 & + & - & non-AD \\
\hline 29 & 72 & M & 0 & 1 & + & + & non-AD \\
\hline 30 & 81 & M & 0 & 1 & - & + & non-AD \\
\hline 31 & 82 & M & 0 & 1 & - & - & non-AD \\
\hline 32 & 78 & $\mathrm{~F}$ & $\mathrm{~N} / \mathrm{A}$ & 1 & - & - & non-AD \\
\hline 33 & 83 & M & $\mathrm{N} / \mathrm{A}$ & 1 & - & - & non-AD \\
\hline 34 & 77 & $\mathrm{~F}$ & 0 & 1 & - & + & non-AD \\
\hline 35 & 79 & $\mathrm{~F}$ & $\mathrm{~N} / \mathrm{A}$ & 1 & - & ++ & non-AD \\
\hline
\end{tabular}

${ }^{a} \mathrm{CDR}$, clinical dementia rating; Braak, Braak staging; SP, senile plaque; IA, intracellular amyloid; NP diagnosis, neuropathological diagnosis; AD, Alzheimer's disease. + , mild reactivity; ++ , moderate reactivity; +++ , strong reactivity; - , not detected; N/A, not available.

the antisoluble amyloid oligomer antibody (A11) developed by Glabe and colleagues; A11-positive staining existed only in human AD brains but not in Tg2576 mice brains (21). Although the production of conformationsensitive antibodies targeting oligomers has been attempted by direct in vivo intracellular selection by Meli et al., almost no intracellular staining was observed in human brains (22). Hoshi and colleagues showed that monoclonal antibodies against amylospheroid, one of toxic $\mathrm{A} \beta$ aggregates associated with $\mathrm{AD}$ pathology,
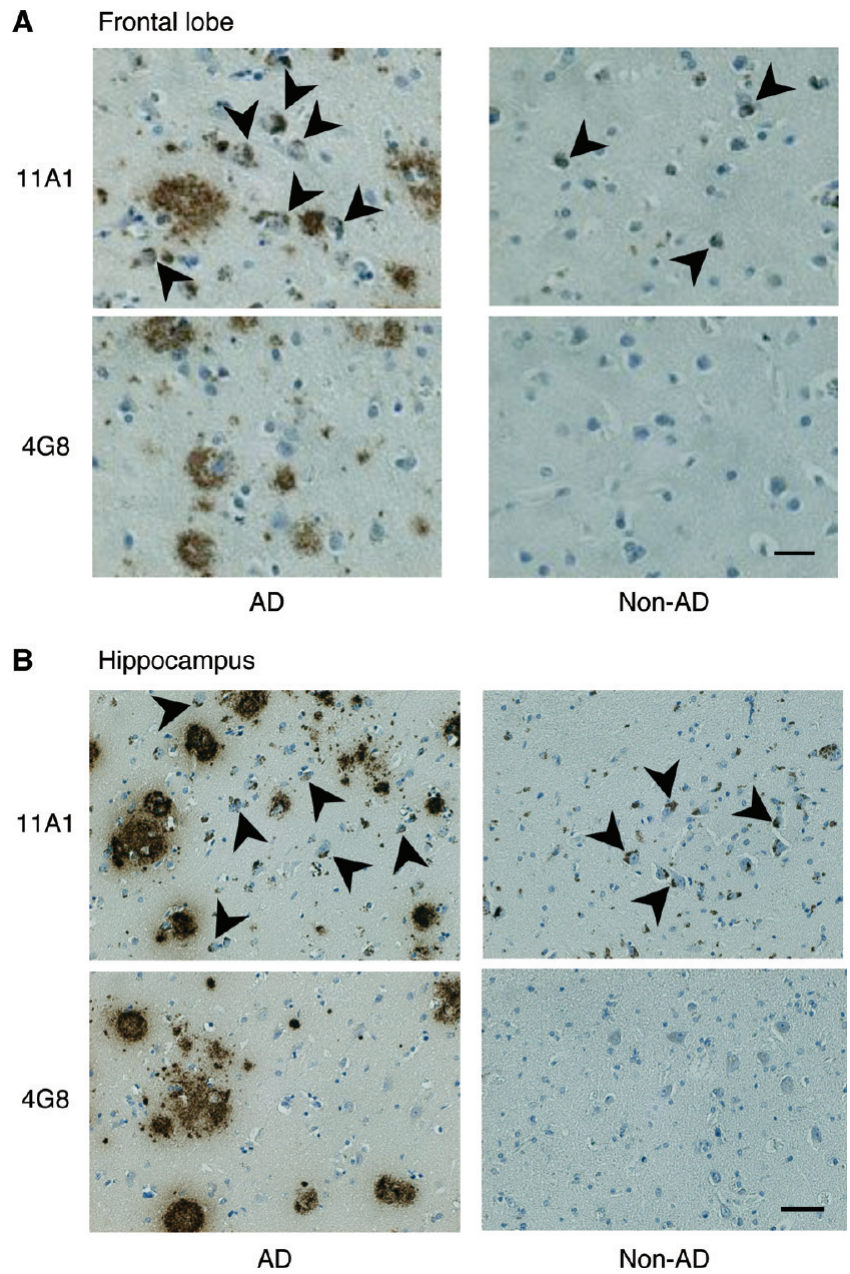

Figure 4. Immunohistochemistry in (A) the frontal lobe of human $\mathrm{AD}$ (case 1) and non-AD (case 18) patients and the hippocampus of human AD patient (case 1) and non-AD individual (case 18) using $11 \mathrm{~A} 1$ (upper) and 4G8 (lower) antibodies, respectively. The scale bar in (A) and (B) represents 50 and $100 \mu \mathrm{m}$, respectively. Arrowheads indicate the staining of intracellular $\mathrm{A} \beta$ within the cells detected only in the 11A1-treated sections.

bound to only extracellular amyloid plaques in human brain sections (23). 11A1 is thus a unique antibody that preferably recognizes intracellular amyloid in human brain along with senile plaques.

As summarized in Table 1, moderate or strong reactivity for intracellular amyloid was frequently observed in almost all $\mathrm{AD}$ patients examined, while moderate staining was seen even in some of non-AD individuals (case 19 and 35), suggesting that intracellular amyloid could be involved in the progression of $\mathrm{AD}$. Intracellular $\mathrm{A} \beta$ may be more important than extracellular $\mathrm{A} \beta$ because intraneuronal $\mathrm{A} \beta$ deposition frequently precedes extracellular $\mathrm{A} \beta$ accumulation in the human brain (24-29). Recently, mitochondrial toxicity, proteasome impairment, and synaptic damage due to intracellular $\mathrm{A} \beta$ have been suggested (28).

Ohyagi and colleagues (30) reported the enhancement of immunoreactivity for intraneuronal $\mathrm{A} \beta 42$ by autoclaving 


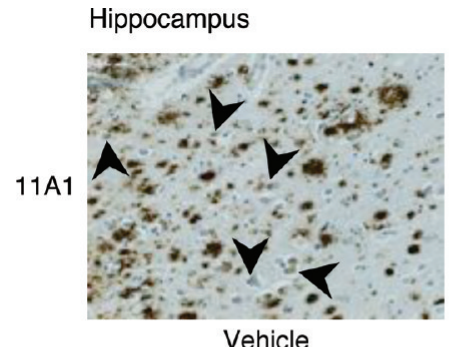

Vehicle
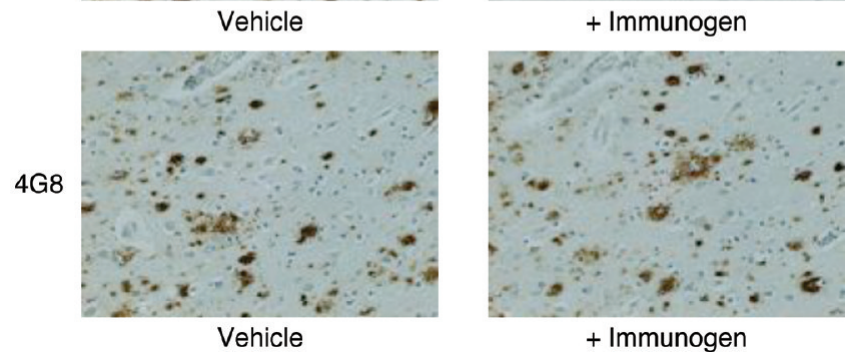

Figure 5. Inhibition assay in AD patient (case 2) by $11 \mathrm{~A} 1,4 \mathrm{G} 8$ alone, or with the immunogen of 11A1 (200-fold molar excess) as indicated. Arrowheads indicate the staining of intracellular $\mathrm{A} \beta$ within the cells. The scale bar represents $100 \mu \mathrm{m}$.

and the reduction by conventional protocols just using formic acid in human sections. If $11 \mathrm{~A} 1$ is conformation-, but not sequence-sensitive, formic acid treatment may somewhat alter the conformation of depositing $\mathrm{A} \beta$. Recently, Christensen et al. revealed that formic acid treatment may be essential for staining highly aggregated $\mathrm{A} \beta$ in neurons (31). 11A1 may detect highly aggregated $\mathrm{A} \beta$, which has a stable conformation against FA treatment in AD patients but not in the AD mouse model, although there are already other AD mouse models, such as the $3 \times$ Tg mouse reported by Oddo et al. (32), which shows preferably abundant intraneuronal $\mathrm{A} \beta$. Alternatively, the possibility cannot be completely ruled out that $11 \mathrm{~A} 1$ could bind to other intracellular proteins with a sequence similar to $\mathrm{A} \beta$ with the turn at positions 22 and 23.

\section{Recognition of A $\beta$ Low-Molecular Weight- Oligomers rather than Monomer in Human AD Brains by 11A1}

To address the question whether $11 \mathrm{~A} 1$ can recognize $\mathrm{A} \beta$ oligomers in human brain, Western blotting was carried out using the Tris-buffered saline (TBS)-soluble fraction of frontal lobe tissues. Notably, in the lowmolecular weight region of AD tissues, $11 \mathrm{~A} 1$ potently reacted with low-molecular weight-oligomers (supposed to be mainly trimer) band (Figure 7A), while 4G8 and $82 \mathrm{E} 1$, whose epitope is the N-terminus of $\mathrm{A} \beta$ (33), strongly reacted only with the monomer of $\mathrm{A} \beta$ (Figure 7A, arrowhead). These data are consistent with our previous reports (15) describing the turn at positions 22 and 23 can induce the oligomerization of $\mathrm{A} \beta 42$.

On the other hand, in the high-molecular weight region, 11A1 exhibited a slightly different pattern from

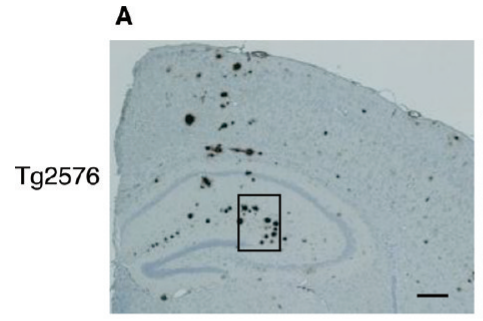

B

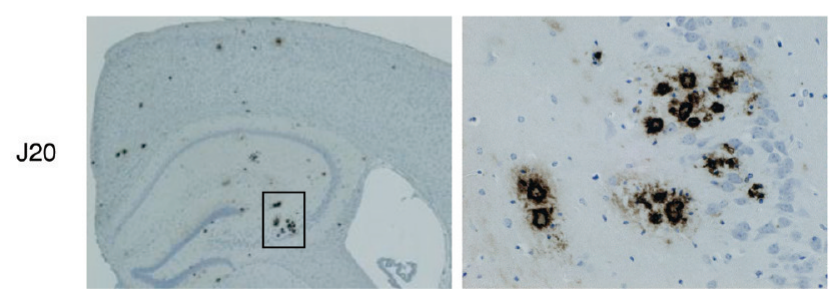

Figure 6. (A) Immunohistochemistry of the 11A1 antibody in the hippocampus and cortex of two representative APP transgenic mice (upper, female Tg2576 at 28 months old; lower, female J20 at 12 months old). The scale bar represents $500 \mu \mathrm{m}$. (B) High magnification of the area in box as shown in (A). The scale bar represents $50 \mu \mathrm{m}$.

4G8 and 82E1 (Figure 7A). The band pattern against anti-C-terminal APP antibody was different from that of 11A1 in the TBS-soluble fractions of AD (Figure 7B). Anti-C-terminal APP antibody reacts with three isoforms of APP (APP695, APP751, and APP770), but not with secreted APP $\alpha$ and $\operatorname{APP} \beta$ after the $\alpha$ - and $\beta$-cut of APP, respectively (34). The 82E1 antibody does not show any cross-reactivity with APP (33). Furthermore, 11A1 failed to detect recombinant human APP, while anti-N-terminal APP antibody surely bound APP, whose presence was confirmed by Coomassie brilliant blue (CBB) staining (Figure 7C). These suggest that highmolecular weight bands might have originated from $\mathrm{A} \beta$ aggregates, but not APP. To check the authenticity of the antigenicity of $11 \mathrm{~A} 1$, an absorption test using the immunogen was carried out (Figure 7D) because Western blotting generally has the problem that protein conformation is basically denatured during SDS-PAGE. As shown in Figure 7D, almost no bands for the low-molecular weight-oligomers were obtained after preincubation of $11 \mathrm{~A} 1$ with its immunogen (200-fold molar excess), whereas weak bands in the high-molecular weight region were found. These results support the more preferable immunoreactivity of $11 \mathrm{~A} 1$ for the low-molecular weight-oligomers; however, the denatured condition under SDS-PAGE might affect the amount of soluble $\mathrm{A} \beta$ oligomer detected in $\mathrm{AD}$ brains because $11 \mathrm{~A} 1$ is supposed to be conformation-sensitive.

In the TBS-insoluble fraction of brain tissue, 11A1 reacted with the monomer band (Figure 7E, arrowhead) along with lots of mixed high-molecular weight-aggregates, whose pattern was almost compatible with those of other 


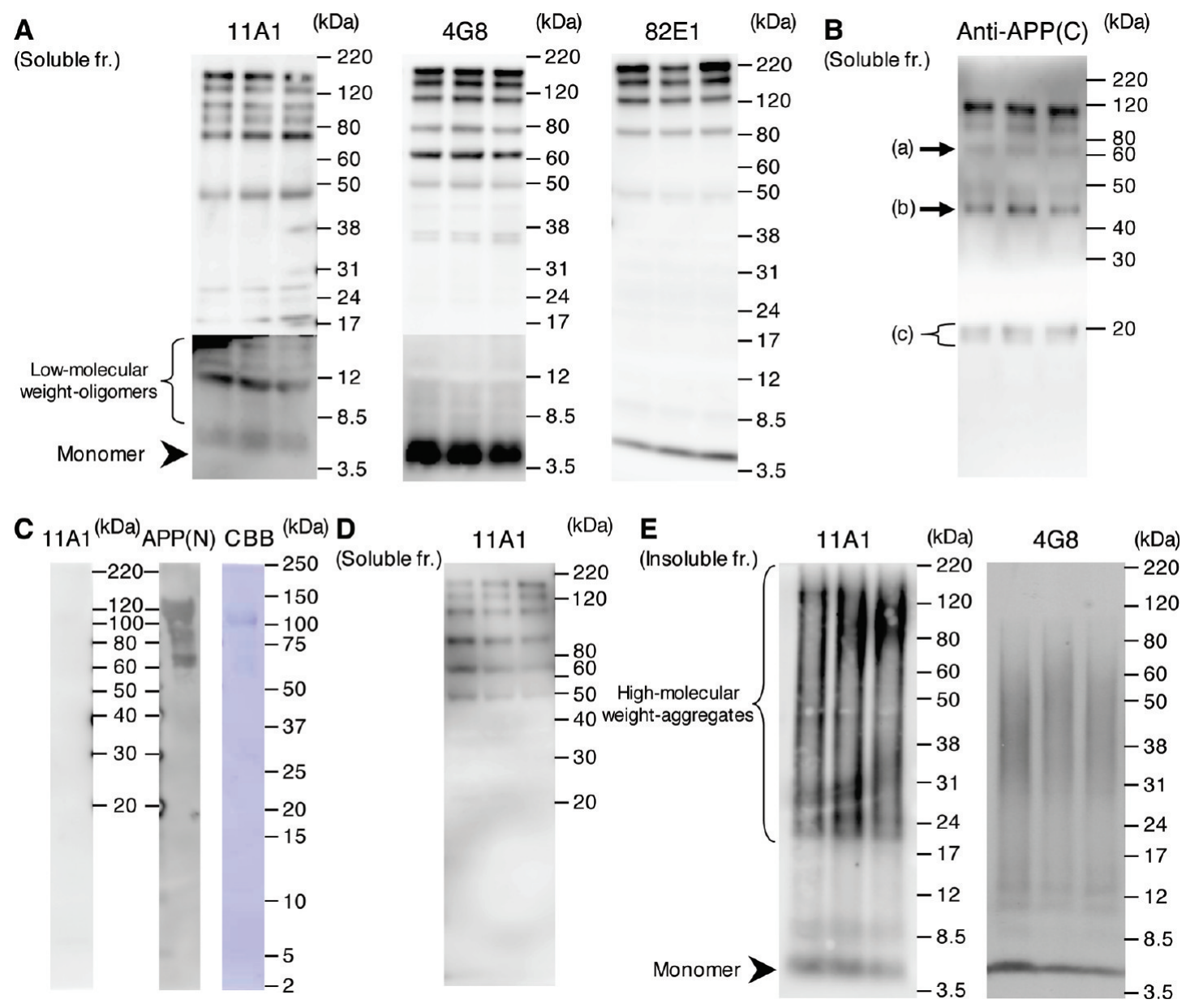

Figure 7. Western blotting of (A, B, D) TBS-soluble or (E) TBS-insoluble fractions of AD patients (case 3-5 in Table 1) and (C) recombinant human APP using (A, C, D , E) the indicated anti-A $\beta$ antibodies; 11A1, 4G8, and 82E1 or anti-N-terminal APP antibody, (B) anti-C-terminal APP antibody. In the absorption test of D, the immunogen of $11 \mathrm{~A} 1$ (200-fold molar excess) was used in AD patients (case 3-5). Arrowheads indicate $\mathrm{A} \beta$ monomers. The molecular markers of the $\mathrm{kDa}$ unit are shown together with blots. In $\mathrm{B}, \mathrm{a}-\mathrm{c}$ represent the lamin $(70 \mathrm{kDa}), \beta$-actin $(42 \mathrm{kDa})$, and $\mathrm{C}$-terminal fragments $(\mathrm{CTFs} ; 12-14 \mathrm{kDa})$, respectively, in which the lamin and $\beta$-actin were used as an internal standard. CBB: Coomassie brilliant blue.

conventional antibodies described in Saido et al. (35). In contrast, $4 \mathrm{G} 8$ detected the $\mathrm{A} \beta$ monomer more clearly than the high-molecular weight-aggregates in the insoluble fraction (Figure 7E); this supports that $11 \mathrm{~A} 1$ can be conformation-sensitive because the $\mathrm{A} \beta$ monomer derived from the insoluble fraction is highly denatured by formic acid.

\section{Conclusions}

In this work, we developed a unique antibody, $11 \mathrm{~A} 1$, against the toxic conformer of $\mathrm{A} \beta 42$, and 11A1 significantly detected intracellular as well as extracellular $\mathrm{A} \beta$ in human brain sections, and low-molecular weightoligomers of $\mathrm{A} \beta$ in human brain extracts. A low but significant level of intracellular $\mathrm{A} \beta$ even in non-AD individuals suggests that $11 \mathrm{~A} 1$ might recognize lowmolecular weight-oligomers of $\mathrm{A} \beta$ with the potential for $\mathrm{AD}$ within the cells in human brains, although we should take into account that multiple manipulations and wash steps in the experiments could induce soluble $\mathrm{A} \beta$ oligomers in the brain extracts, which are known to be metastable. Further research will be needed to elucidate the cell types (e.g., neuron, microglia, and astrocyte) stained by $11 \mathrm{~A} 1$ and whether intracellular $\mathrm{A} \beta$ stained in the human brains is an oligomer. To clarify whether toxic oligomers of $\mathrm{A} \beta 42$ with a turn at positions 22 and 23 exist in the brain of AD patients is our next goal. 11A1 recognizes the turn structure in the middle portion of $\mathrm{A} \beta$ sequence as an epitope, which is quite different from conventional anti-A $\beta$ middle sequencespecific antibodies, leading to a difference in intracellular immunoreactivity in human brains. 11A1 might become a new tool to investigate the role of intracellular amyloid in the pathogenesis of AD and be applicable to anti-A $\beta$ therapeutic approaches. 


\section{Methods}

\section{Development of Monoclonal Antibody (11A1) for the} Toxic Conformer of $\mathrm{A} / \boldsymbol{\beta 4 2}$ and the Enzyme Immunoassay G9C, E22P-A $\beta 9-35$ (CYEVHHQKLVFFAPDVGSNKGAIIGLM) as an immunogen for the toxic conformer of A $\beta 42$, was synthesized by the method described previously (36). The N-terminal glycine residue was replaced with a cysteine residue to bind to a carrier protein, bovine thyroglobulin, following the standard method (33). Mice (BALB/c, Charles River, Japan) were immunized weekly for a month with the conjugated G9C, E22P-A $\beta 9-35$ (50 $\mu \mathrm{g} /$ mouse) mixed with complete Freund's adjuvant once followed by booster injections with the antigen in incomplete Freund's adjuvant three times. A 96-well Maxisorp plate (Nunc, Denmark) coated with various $\mathrm{A} \beta 42$ mutants $(50 \mu \mathrm{g} / \mathrm{mL})$ was incubated with the obtained clones for one hour at room temperature, followed by treatment with a horseradish peroxidase-coupled antimouse IgG antibody [Immuno-Biological Laboratories (IBL), Gunma, Japan], and quantified using 3,3',5,5'-tetramethylbenzidine (Pierce, Rockford, IL) or $o$-phenylenediamine dihydrochloride substrate (Sigma, St. Louis, MO). A total of 45 clones were obtained and screened by the ability to bind $\mathrm{A} / 342$ mutants (E22P, E22Q, E22K, E22G, D23N) with a propensity to form a $\beta$-turn at positions 22 and 23 (17), and then subcloned to obtain seven monoclones. The screening was repeated to exclude weak or false positives. They were further screened by the inability to bind $\mathrm{E} 22 \mathrm{~V}-\mathrm{A} \beta 42$ without a propensity to form a turn at positions 22 and 23 to yield $11 \mathrm{~A} 1$, whose isotype is $\operatorname{IgG} 1$. Mice used for the development of antibodies were maintained and studied according to the protocols approved by the Animal Care Committee of IBL Co., Ltd. The molecular weight of G9C, E22P-A $\beta 9-35$ as an immunogen and E22P-A $\beta 9-35$ for an absorption experiment were confirmed using matrix assisted laser desorption ionization-time-of-flight-mass spectrometry (MALDI-TOF-MS) (Supporting Information, Figure S1) as reported previously (37).

Binding Kinetics by Surface Plasmon Resonance (SPR)

Binding affinity tests were performed using a BIAcore X100 biosensor (BIAcore, Inc., Uppsala, Sweden). A CM5 sensor chip was activated as recommended by the manufacturer using an equimolar mix of $N$-hydroxysuccinimide (NHS) and $N$-ethyl- $N^{\prime}$-(dimethylaminopropyl)carbodiimide (EDC), coupled with $5 \mu \mathrm{M} \mathrm{A} \beta 42$ in sodium acetate buffer ( $\mathrm{pH} 4.8$ ), and then blocked with ethanolamine. The antibody was dissolved in phosphate buffered saline (PBS) containing $0.1 \%$ Tween-20 running buffer ( $\mathrm{pH}$ 7.4) and injected over the chipimmobilized $\mathrm{A} \beta 42$ at a flow rate of $10 \mu \mathrm{L} / \mathrm{min}$. Guanidine hydrochloride $(5 \mathrm{M})$ was utilized as a regeneration buffer. The association and dissociation rate constants $\left(k_{\mathrm{a}}\right.$ and $\left.k_{\mathrm{d}}\right)$ were determined using different antibody concentrations of 225,450 , 900,1800 , and $3600 \mathrm{nM}$. Samples of $90 \mu \mathrm{L}$ were injected. Dissociation data were collected with flowing running buffer for $120 \mathrm{~s}$. The values of the observed response units (RU) obtained in the sample cells minus the RU obtained from a reference cell were used for analysis. Kinetic parameters were evaluated using BIAevaluation 3.1 software (BIAcore).

\section{Cytotoxicity Test Using PC12 Cells}

To evaluate the cytotoxicity of A $\beta$ using the MTT assay, we used PC12 cells, which have the potential to differentiate into neural cells. Since they are sensitive to $\mathrm{A} \beta$ proteins, they are generally used for estimating cytotoxicity as a neurotoxicity model (38). PC12 cells (RCB0009) was provided by the RIKEN BRC through the National Bio-Resource Project of the MEXT, Japan. A $\beta 42$ or E22P-A $\beta 42$ alone or with antibody (11A 1 or $4 \mathrm{G} 8)$ at the concentration of $0.36 \mu \mathrm{M}$ $(0.054 \mathrm{mg} / \mathrm{mL})$ was added to the undifferentiated cells, and incubated at $37^{\circ} \mathrm{C}$ for $48 \mathrm{~h}$; initially $3.6 \mu \mathrm{M}(0.54 \mathrm{mg} / \mathrm{mL})$ was the maximum solubility in buffer. The protein concentrations of antibodies after the MTT assay were determined using the DC protein assay (Bio-Rad Laboratories, Hercules, CA) according to the protocol of the manufacturer with bovine serum albumin used as the standard. The concentration of each $\mathrm{A} \beta$ used was $0.1 \mu \mathrm{M}$, which was close to the $\mathrm{IC}_{50}$ value of $\mathrm{E} 22 \mathrm{P}-\mathrm{A} \beta 42$. The details of the experimental procedure have been described previously (17).

\section{Immunohistochemical Analysis}

The frontal lobe and hippocampus in brain sections of AD ( 7 male, 10 female) and non-AD control (13 male, 5 female) individuals (Table 1) were used in the experiment with written informed consent obtained from the patients' families, and the consent was approved by the Ethical Committee of Tokyo Metropolitan Institute of Gerontology and Tokyo Metropolitan Geriatric Hospital. The National Institute on AgingReagan criteria modified were adopted for diagnosis of $\mathrm{AD}$ (39). The normal controls were defined as clinical documentation of unimpaired cognition as well as minimal senile changes, consisting of Braak's neurofibrillary tangle stage equal to or less than II, senile plaque stage equal to or less than A (40), and lacking any vascular, inflammatory or traumatic changes or tumors.

In two strains of APP transgenic mice [Tg2576 (41) at 28 months old and $\mathbf{J} 20$ (42) at 12 months old], brains were dissected, fixed in a 4\% paraformaldehyde (Wako, Osaka, Japan) for 3-5 days, embedded in paraffin, and sectioned using a microtome at $5 \mu \mathrm{m}$ thicknesses by standard techniques. The animals were housed in a 12-h light/dark cycle and were fed ad libitum. The mice used in the immunohistochemical study were maintained and studied according to protocols approved by the Animal Care Committee of the Tokyo Metropolitan Institute of Gerontology.

The human or mice brain sections were deparaffinized, rehydrated, and washed in PBS, followed by a brief treatment with formic acid. After incubation in 3\% hydrogen peroxide in methanol to prevent endogenous peroxidation, the sections were blocked with $10 \%$ normal goat serum in PBS, followed by incubation with the primary antibody $[11 \mathrm{~A} 1 ; 5 \mu \mathrm{g} / \mathrm{mL}$, $4 \mathrm{G} 8 ; 1 \mu \mathrm{g} / \mathrm{mL}$ (Signet, Dedham, MA)] overnight at $4{ }^{\circ} \mathrm{C}$. Then, the sections were incubated with biotinylated secondary antibody (Vector Laboratories, Burlingame, CA, USA) for $30 \mathrm{~min}$ at room temperature. Immunoreactivity was visualized using an $\mathrm{ABC}$ Elite kit (ABC Elite, Vector Laboratories, Burlingame, CA) in accordance with the manufacturer's protocol. 3,3'-Diaminobenzidine (Sigma) was used as a chromogen. The sections were counterstained with hematoxylin.

\section{Preparation of Human Brain Extracts and Western Blotting Analysis}

The frontal lobe in the brain of AD patients and non-AD control individuals was used for biochemical experiments. 
The definite diagnosis of $\mathrm{AD}$ was based on the presence of neurofibrillary tangles and neuritic plaques in the hippocampal formation and neocortical area. The neuropathological diagnosis of individuals used is summarized in Table 1.

Tissue in frontal lobe was homogenized in 10 volumes (w/v) of $50 \mathrm{mM}$ Tris- $\mathrm{HCl}$ buffer (pH 7.6) containing $150 \mathrm{mM}$ $\mathrm{NaCl}$ (TBS), a mixture of protease inhibitors (Complete EDTA-free, Roche Diagnostics, Indianapolis, IN, USA), and a mixture of phosphatase inhibitors (Phos STOP, Roche Diagnostics) supplemented with $0.7 \mu \mathrm{g} / \mathrm{mL}$ pepstatin A (Peptide Institute, Osaka, Japan) and $1 \mathrm{mM}$ phenylmethylsulfonyl fluoride (Sigma). The homogenates were centrifuged at $186,000 \times g$ for $30 \mathrm{~min}$ at $4{ }^{\circ} \mathrm{C}$ using an Optima TL ultracentrifuge and a TLA100.4 rotor (Beckman, Palo Alto, CA, USA) to give supernatant (soluble) and pellet (insoluble) fractions. The pellet was dissolved by sonication in $70 \%$ formic acid containing a mixture of protease inhibitors based on the protocol of Saido et al. (35). The solubilized pellet was centrifuged at $186,000 \times g$ for $30 \mathrm{~min}$ at $4{ }^{\circ} \mathrm{C}$ for $30 \mathrm{~min}$, after which the supernatant was neutralized with $1 \mathrm{M}$ Tris base of $\mathrm{pH} 11(1: 20, \mathrm{v}: \mathrm{v})$ as an insoluble fraction.

The fractions $(2 \mu \mathrm{g} / \mu \mathrm{L})$ were subjected to Western blotting using 10-20\% Tricine gels (Invitrogen, Gaithersburg, MD, USA) and transferred to PVDF membrane $(0.2 \mu \mathrm{m}$ pore size, Bio-Rad, Hercules, CA, USA). Recombinant human APP with protease nexin II was used to evaluate the cross-reactivity of $11 \mathrm{~A} 1$ with APP (R\&D, Minneapolis, MN, USA), and Coomassie brilliant blue was utilized to confirm the existence of proteins. Membranes were heated in PBS (1 min, microwave), blocked in TBS-T (TBS containing $0.01 \%$ Tween-20, $2.5 \%$ skim milk), and incubated with the primary antibody overnight at $4{ }^{\circ} \mathrm{C}[11 \mathrm{~A} 1 ; 5 \mu \mathrm{g} / \mathrm{mL}, 4 \mathrm{G} 8 ; 1 \mu \mathrm{g} / \mathrm{mL}, 82 \mathrm{E} 1$ (IBL); $1 \mu \mathrm{g} / \mathrm{mL}$, N-terminal or C-terminal APP (IBL); $1 \mu \mathrm{g} / \mathrm{mL}$, actin (Sigma); $1 \mu \mathrm{g} / \mathrm{mL}$, lamin (ImmuQuest); $1 \mu \mathrm{g} / \mathrm{mL}$, followed by washing with TBS-T and treatment with the secondary antibody $(1 \mathrm{~h}$, room temperature). The development was performed with enhanced chemiluminescence reagent (GE Healthcare, Buckinghamshire, England) and quantified using LAS-3000 (Fujifilm, Tokyo, Japan).

\section{Supporting Information Available}

Additional data including extended figures. This material is available free of charge via the Internet at http://pubs.acs.org.

\section{Author Information}

\section{Corresponding Author}

${ }^{*}$ To whom correspondence should be addressed. Tel: +81-3-39643241 (T.S.); +81-75-753-6281 (K.I.). Fax: +81-3-3579-4776 (T.S.); +81-75-753-6284 (K.I.). E-mail: shimizut@tmig.or.jp (T.S.); irie@kais.kyoto-u.ac.jp (K.I.).

\section{Author Contributions}

K.M., N.K., T.Shir., T.Shim., and K.I. designed research; K.M., Y.H-S., N.M., and Y.N. performed research; Y.M., H.H., and S.M. contributed new reagents/analytic tools; K.M., N.K., T.Shir., T.Shim., and K.I. analyzed data; and K.M., T.Shim., and K.I. wrote the paper.

\section{Funding Sources}

This research was supported in part by Grants-in-Aid for Scientific Research (A) (Grants 18208011 and 21248015 to K.I.), Scientific Research on Priority Areas (Grant 17025051 to T.Shir.), and the Promotion of Science for Young Scientists (Grants 16.1215 and 19.0403 to K.M. and 18.3327 to Y.M.) from the Ministry of Education, Culture, Sports, Science and Technology of the Japanese Government.

\section{Acknowledgment}

K.M. and Y.M. are Research Fellows of the Japan Society for the Promotion of Science. We thank Dr. Hiroyuki Fukuda at the Institute of Medical Science, The University of Tokyo, for MALDI-TOF-MS measurements, Drs. Kazumitsu Ueda, Noriyuki Kioka, Yasuhisa Kimura at the iCeMS, Division of Applied Life Sciences, Graduate School of Agriculture, Kyoto University, for use of the SPR biosensor, and Ms. Eiko Moriizumi and Mrs. Yusuke Ozawa and Shinya Yokoyama at Tokyo Metropolitan Institute of Gerontology for technical assistance.

\section{Abbreviations}

$\mathrm{AD}$, Alzheimer's disease; $\mathrm{A} \beta$, amyloid $\beta$; APP, amyloid precursor protein; CBB, Coomassie brilliant blue; MALDITOF-MS, matrix assisted laser desorption ionization-timeof-flight-mass spectrometry; PBS, phosphate buffered saline; SPR, surface plasmon resonance; TBS, Tris-buffered saline.

\section{References}

1. Glenner, G. G., and Wong, C. W. (1984) Alzheimer's disease: Initial report of the purification and characterization of a novel cerebrovascular amyloid protein. Biochem. Biophys. Res. Commun. 120, 885-890.

2. Masters, C. L., Simms, G., Weinman, N. A., Multhaup, G., McDonald, B. L., and Beyreuther, K. (1985) Amyloid plaque core protein in Alzheimer disease and Down syndrome. Proc. Natl. Acad. Sci. U. S. A. 82, 4245-4249.

3. Haass, C., and Selkoe, D. J. (2007) Soluble protein oligomers in neurodegeneration: Lessons from the Alzheimer's amyloid $\beta$-peptide. Nat. Rev. Mol. Cell. Biol. 8, 101-112.

4. Behl, C., Davis, J. B., Lesley, R., and Schubert, D. (1994) Hydrogen peroxide mediates amyloid beta protein toxicity. Cell 77, 817-827.

5. Barnham, K. J., Masters, C. L., and Bush, A. I. (2004) Neurodegenerative diseases and oxidative stress. Nat. Rev. Drug Discovery 3, 205-214.

6. Varadarajan, S., Yatin, S., Aksenova, M., and Butterfield, D. A. (2000) Review: Alzheimer's amyloid $\beta$-peptideassociated free radical oxidative stress and neurotoxicity. J. Struct. Biol. 130, 184-208.

7. Murakami, K., Irie, K., Ohigashi, H., Hara, H., Nagao, M., Shimizu, T., and Shirasawa, T. (2005) Formation and stabilization model of the 42-mer Abeta radical: implications for the long-lasting oxidative stress in Alzheimer's disease. J. Am. Chem. Soc. 127, 15168-15174. 
8. Walsh, D. M., Klyubin, I., Fadeeva, J. V., Cullen, W. K., Anwyl, R., Wolfe, M. S., Rowan, M. J., and Selkoe, D. J. (2002) Naturally secreted oligomers of amyloid beta protein potently inhibit hippocampal long-term potentiation in vivo. Nature 416, 535-539.

9. Roychaudhuri, R., Yang, M., Hoshi, M. M., and Teplow, D. B. (2009) Amyloid $\beta$-protein assembly and Alzheimer disease. J. Biol. Chem. 284, 4749-4753.

10. Schenk, D., Barbour, R., Dunn, W., Gordon, G., Grajeda, H., Guido, T., Hu, K., Huang, J., Johnson-Wood, K., Khan, K., Kholodenko, D., Lee, M., Liao, Z., Lieberburg, I., Motter, R., Mutter, L., Soriano, F., Shopp, G., Vasquez, N., Vandevert, C., Walker, S., Wogulis, M., Yednock, T., Games, D., and Seubert, P. (1999) Immunization with amyloid- $\beta$ attenuates Alzheimer-disease-like pathology in the PDAPP mouse. Nature 400, 173-177.

11. Morgan, D., Diamond, D. M., Gottschall, P. E., Ugen, K. E., Dickey, C., Hardy, J., Duff, K., Jantzen, P., DiCarlo, G., Wilcock, D., Connor, K., Hatcher, J., Hope, C., Gordon, M., and Arendash, G. W. (2000) A beta peptide vaccination prevents memory loss in an animal model of Alzheimer's disease. Nature 408, 982-985.

12. Orgogozo, J. M., Gilman, S., Dartigues, J. F., Laurent, B., Puel, M., Kirby, L. C., Jouanny, P., Dubois, B., Eisner, L., Flitman, S., Michel, B. F., Boada, M., Frank, A., and Hock, C. (2003) Subacute meningoencephalitis in a subset of patients with AD after A $\beta 42$ immunization. Neurology 61 , 46-54.

13. Holmes, C., Boche, D., Wilkinson, D., Yadegarfar, G., Hopkins, V., Bayer, A., Jones, R. W., Bullock, R., Love, S., Neal, J. W., Zotova, E., and Nicoll, J. A. (2008) Longterm effects of A $\beta 42$ immunisation in Alzheimer's disease: Follow-up of a randomised, placebo-controlled phase I trial. Lancet 372, 216-223.

14. Soscia, S. J., Kirby, J. E., Washicosky, K. J., Tucker, S. M., Ingelsson, M., Hyman, B., Burton, M. A., Goldstein, L. E., Duong, S., Tanzi, R. E., and Moir, R. D. (2010) The Alzheimer's disease-associated amyloid beta-protein is an antimicrobial peptide. PLoS One 5, e9505.

15. Masuda, Y., Uemura, S., Ohashi, R., Nakanishi, A., Takegoshi, K., Shimizu, T., Shirasawa, T., and Irie, K. (2009) Identification of physiological and toxic conformations in A $\beta 42$ aggregates. ChemBioChem 10, 287-295.

16. Chou, P. Y., and Fasman, G. D. (1977) Beta-turns in proteins. J. Mol. Biol. 115, 135-175.

17. Murakami, K., Irie, K., Morimoto, A., Ohigashi, H., Shindo, M., Nagao, M., Shimizu, T., and Shirasawa, T. (2003) Neurotoxicity and physicochemical properties of Abeta mutant peptides from cerebral amyloid angiopathy: Implication for the pathogenesis of cerebral amyloid angiopathy and Alzheimer's disease. J. Biol. Chem. 278, 4617946187.

18. Morimoto, A., Irie, K., Murakami, K., Masuda, Y., Ohigashi, H., Nagao, M., Fukuda, H., Shimizu, T., and Shirasawa, T. (2004) Analysis of the secondary structure of $\beta$-amyloid (A $\beta 42$ ) fibrils by systematic proline replacement. J. Biol. Chem. 279, 52781-52788.

19. Williams, A. D., Portelius, E., Kheterpal, I., Guo, J. T., Cook, K. D., Xu, Y., and Wetzel, R. (2004) Mapping abeta amyloid fibril secondary structure using scanning proline mutagenesis. J. Mol. Biol. 335, 833-842.

20. Wisniewski, H. M., Wen, G. Y., and Kim, K. S. (1989) Comparison of four staining methods on the detection of neuritic plaques. Acta Neuropathol. 78, 22-27.

21. Kayed, R., Head, E., Thompson, J. L., McIntire, T. M., Milton, S. C., Cotman, C. W., and Glabe, C. G. (2003) Common structure of soluble amyloid oligomers implies common mechanism of pathogenesis. Science 300, 486-489.

22. Meli, G., Visintin, M., Cannistraci, I., and Cattaneo, A. (2009) Direct in vivo intracellular selection of conformationsensitive antibody domains targeting Alzheimer's amyloidbeta oligomers. J. Mol. Biol. 387, 584-606.

23. Noguchi, A., Matsumura, S., Dezawa, M., Tada, M., Yanazawa, M., Ito, A., Akioka, M., Kikuchi, S., Sato, M., Ideno, S., Noda, M., Fukunari, A., Muramatsu, S., Itokazu, Y., Sato, K., Takahashi, H., Teplow, D. B., Nabeshima, Y., Kakita, A., Imahori, K., and Hoshi, M. (2009) Isolation and characterization of patient-derived, toxic, high mass amyloid beta-protein (Abeta) assembly from Alzheimer disease brains. J. Biol. Chem. 284, 32895-32905.

24. LaFerla, F. M., Troncoso, J. C., Strickland, D. K., Kawas, C. H., and Jay, G. (1997) Neuronal cell death in Alzheimer's disease correlates with apoE uptake and intracellular Abeta stabilization. J. Clin. Invest. 100, 310-320.

25. Gouras, G. K., Tsai, J., Naslund, J., Vincent, B., Edgar, M., Checler, F., Greenfield, J. P., Haroutunian, V., Buxbaum, J. D., Xu, H., Greengard, P., and Relkin, N. R. (2000) Intraneuronal Abeta42 accumulation in human brain. Am. J. Pathol. 156, 15-20.

26. LaFerla, F. M., Green, K. N., and Oddo, S. (2007) Intracellular amyloid-beta in Alzheimer's disease. Nat. Rev. Neurosci. 8, 499-509.

27. Gomez-Ramos, P., and Asuncion Moran, M. (2007) Ultrastructural localization of intraneuronal Abeta-peptide in Alzheimer disease brains. J. Alzheimers Dis. 11, 53-59.

28. Ohyagi, Y. (2008) Intracellular amyloid beta-protein as a therapeutic target for treating Alzheimer's disease. Curr. Alzheimer Res. 5, 555-561.

29. Fernandez-Vizarra, P., Fernandez, A. P., Castro-Blanco, S., Serrano, J., Bentura, M. L., Martinez-Murillo, R., Martinez, A., and Rodrigo, J. (2004) Intra- and extracellular Abeta and PHF in clinically evaluated cases of Alzheimer's disease. Histol. Histopathol. 19, 823-844.

30. Ohyagi, Y., Tsuruta, Y., Motomura, K., Miyoshi, K., Kikuchi, H., Iwaki, T., Taniwaki, T., and Kira, J. (2007) Intraneuronal amyloid beta42 enhanced by heating but counteracted by formic acid. J. Neurosci. Methods 159, 134-138.

31. Christensen, D. Z., Bayer, T. A., and Wirths, O. (2009) Formic acid is essential for immunohistochemical detection of aggregated intraneuronal Abeta peptides in mouse models of Alzheimer's disease. Brain Res. 1301, 116-125.

32. Oddo, S., Caccamo, A., Shepherd, J. D., Murphy, M. P., Golde, T. E., Kayed, R., Metherate, R., Mattson, M. P., Akbari, Y., and LaFerla, F. M. (2003) Triple-transgenic model of Alzheimer's disease with plaques and tangles: Intracellular Abeta and synaptic dysfunction. Neuron 39, 409-421. 
33. Horikoshi, Y., Sakaguchi, G., Becker, A. G., Gray, A. J., Duff, K., Aisen, P. S., Yamaguchi, H., Maeda, M., Kinoshita, N., and Matsuoka, Y. (2004) Development of Abeta terminal end-specific antibodies and sensitive ELISA for Abeta variant. Biochem. Biophys. Res. Commun. 319, 733-737.

34. Selkoe, D. J. (1994) Normal and abnormal biology of the beta-amyloid precursor protein. Annu. Rev. Neurosci. 17, 489-517.

35. Saido, T. C., Iwatsubo, T., Mann, D. M., Shimada, H., Ihara, Y., and Kawashima, S. (1995) Dominant and differential deposition of distinct beta-amyloid peptide species, A beta N3(pE), in senile plaques. Neuron 14, 457-466.

36. Murakami, K., Irie, K., Morimoto, A., Ohigashi, H., Shindo, M., Nagao, M., Shimizu, T., and Shirasawa, T. (2002) Synthesis, aggregation, neurotoxicity, and secondary structure of various A beta 1-42 mutants of familial Alzheimer's disease at positions 21-23. Biochem. Biophys. Res. Commun. 294, 5-10.

37. Irie, K., Oie, K., Nakahara, A., Yanai, Y., Ohigashi, H., Wender, P. A., Fukuda, H., Konishi, H., and Kikkawa, U. (1998) Molecular basis for protein kinase C isozymeselective binding: the synthesis, folding, and phorbol ester binding of the cysteine-rich domains of all protein kinase $\mathrm{C}$ isozymes. J. Am. Chem. Soc. 120, 9159-9167.

38. Shearman, M. S., Ragan, C. I., and Iversen, L. L. (1994) Inhibition of PC12 cell redox activity is a specific, early indicator of the mechanism of beta-amyloid-mediated cell death. Proc. Natl. Acad. Sci. U. S. A. 91, 1470-1474.

39. Murayama, S., and Saito, Y. (2004) Neuropathological diagnostic criteria for Alzheimer's disease. Neuropathology $24,254-260$.

40. Braak, H., and Braak, E. (1991) Neuropathological stageing of Alzheimer-related changes. Acta Neuropathol. $82,239-259$.

41. Hsiao, K., Chapman, P., Nilsen, S., Eckman, C., Harigaya, Y., Younkin, S., Yang, F., and Cole, G. (1996) Correlative memory deficits, Abeta elevation, and amyloid plaques in transgenic mice. Science 274, 99-102.

42. Mucke, L., Masliah, E., Yu, G. Q., Mallory, M., Rockenstein, E. M., Tatsuno, G., Hu, K., Kholodenko, D., Johnson-Wood, K., and McConlogue, L. (2000) Highlevel neuronal expression of abeta 1-42 in wild-type human amyloid protein precursor transgenic mice: synaptotoxicity without plaque formation. J. Neurosci. 20, 4050-4058. 